\title{
Notulae to the Italian flora of algae, bryophytes, fungi and lichens: 4
}

\author{
Sonia Ravera', Alfredo Vizzini ${ }^{2}$, Annalena Cogoni ${ }^{3}$, Michele Aleffi ${ }^{4}$,
} Silvia Assini ${ }^{5}$, Giovanni Bergamo Decarli ${ }^{6}$, Ilaria Bonini ${ }^{7}$, Wolfgang von Brackel ${ }^{8}$, Francesco Cheli ${ }^{7}$, Valeriy Darmostuk ${ }^{9}$, Zuzana Fačkovcováa ${ }^{10}$, Lyubov Gavrylenko', Gabriele Gheza ${ }^{5}$, Anna Guttová ${ }^{10}$, Helmut Mayrhofer ${ }^{11}$, Juri Nascimbene ${ }^{12}$, Luca Paoli ${ }^{7}$, Silvia Poponessi ${ }^{13}$, Giovanna Potenza ${ }^{14}$, Filippo Prosser ${ }^{15}$, Davide Puddu ${ }^{3}$, Domenico Puntillo ${ }^{16}$, Diego Rigotti ${ }^{17}$, Francesco Sguazzin ${ }^{18}$, Alessia Tatti ${ }^{3}$, Roberto Venanzoni ${ }^{13}$

I via del Labaro 54, 00188 Roma, Italy 2 Dipartimento di Scienze della Vita e Biologia dei Sistemi, Università di Torino, Viale P.A. Mattioli 25, 10125 Torino, Italy and Institute for Sustainable Plant Protection (IPSP) - CNR, Viale P.A. Mattioli 25, I-10125, Torino, Italy 3 Dipartimento di Scienze della Vita e dell'Ambiente, Università degli Studi di Cagliari, viale Sant'Ignazio da Laconi 13, 09123 Cagliari, Italy 4 Scuola di Bioscienze e Medicina Veterinaria, Università degli Studi di Camerino, via Pontoni 5, 62032 Camerino (Macerata), Italy 5 Dipartimento di Scienze della Terra e dell'Ambiente, Università di Pavia, Via S. Epifanio 14, 27100 Pavia, Italy 6 Viale Rovereto 7, 38122 Trento, Italy 7 Dipartimento di Scienze della Vita, Università degli Studi di Siena, Via P.A. Mattioli 4, 53100 Siena, Italy 8 Institut für Vegetationskunde und Landschaftsökologie, Georg-Eger-Str. 1b, DE-91334 Hemhofen, Germany 9 Department of Botany, Kherson State University, Universitetska St. 27, 73000 Kherson, Ukraine 10 Institute of Botany, Slovak Academy of Sciences, Dúbravská cesta 9, SK-84523 Bratislava, Slovakia II Institut für Pflanzenwissenschaften, Karl-FranzensUniversität Graz, Holteigasse 6, A-8010 Graz, Austria 12 Dipartimento di Scienze Biologiche, Geologiche e Ambientali, Università di Bologna, Via Irnerio 42, 40126 Bologna, Italy 13 Dipartimento di Chimica, Biologia e Biotecnologia, Università degli Studi di Perugia, Borgo XX giugno 74, 06121 Perugia, Italy 14 Scuola di scienze Agrarie, Forestali, Alimentari ed Ambientali, Dipartimento di Biologia, Difesa e Biotecnologie AgroForestali, Università della Basilicata, Viale dell'Ateneo Lucano 10, 85100 (Potenza), Italy 15 Fondazione Museo Civico di Rovereto, Largo S. Caterina 41, 38068 Rovereto (Trento), Italy 16 Museo di Storia Naturale della Calabria ed Orto Botanico, Università della Calabria, 87036 Arcavacata di Rende (Cosenza), Italy 17 Via alle Gemelle 7, 38121 Trento, Italy 18 Via Selvotta, 61, 33055 Muzzana del Turgnano (Udine), Italy

Corresponding author: Sonia Ravera (sonia.ravera@unimol.it)

Academic editor: L. Peruzzi | Received 17 October 2017 | Accepted 30 October 2017 | Published 21 November 2017

Citation: Ravera S, Vizzini A, Cogoni A, Aleffi M, Assini S, Bergamo Decarli G, Bonini I, von Brackel W, Cheli F, Darmostuk V, Fačkovcová Z, Gavrylenko L, Gheza G, Guttová A, Mayrhofer H, Nascimbene J, Paoli L, Poponessi S, Potenza G, Prosser F, Puddu D, Puntillo D, Rigotti D, Sguazzin F, Tatti A, Venanzoni R (2017) Notulae to the Italian flora of algae, bryophytes, fungi and lichens: 4. Italian Botanist 4: 76-86. doi: 10.3897/italianbotanist.4.21671

Copyright Sonia Ravera et al. This is an open access article distributed under the terms of the Creative Commons Attribution License (CC BY 4.0), which permits unrestricted use, distribution, and reproduction in any medium, provided the original author and source are credited. 


\section{Abstract}

In this contribution, new data concerning bryophytes, fungi and lichens of the Italian flora are presented. It includes new records and confirmations for the bryophyte genera Campylopus, Paludella, Tortula, and Conocephalum, the fungal genera Agonimia, Buelliella, Entorrhiza, Filicupula, Poronia, and Sporisorium, the lichen genera Cladonia, Dibaeis, Lasallia, and Rhizocarpon.
\end{abstract}

\title{
Keywords
}

Ascomycota, Basidiomycota, Bryidae, Marchantiidae, floristic data

\section{How to contribute}

The text of the records should besubmitted electronically to: Cecilia Totti (c.totti@univpm.it) for algae, Annalena Cogoni (cogoni@unica.it) for bryophytes, Alfredo Vizzini (alfredo.vizzini@unito.it) for fungi, Sonia Ravera (sonia.ravera@unimol.it) for lichens.

\section{Floristic records}

\section{Bryophytes}

\section{Campylopus introflexus (Hedw.) Brid. (Leucobryaceae)}

+ TAA: Predacava, tra Lisignago e Masen (Trento) (UTM WGS84: 32T 668435.5115211), 685 m, 11 March 2017, F. Prosser (Herb. Prosser No. 00701); Laghetti di Marco (Trento), along the itinerary in the proximity of the Laghetto Nord (UTM WGS84: 32T 656576.5079954), 175 m, 7 April 2017, F. Prosser (Herb. Prosser No. 00722). - Species new for the flora of Trentino-Alto Adige.

The species has a wide distribution in the southern Hemisphere and is invasive in North America and Europe (Priede and Mežaka 2016). In Italy, it was reported by Puglisi et al. (2015) and Scortegagna (2016). The two populations recorded here are situated along paths, a usual habitat for this species (see Puglisi et al. 2015). Both populations are small,covering a few square decimeters. At Laghetti di Marco, a biotope of limestone boulders, this acidophilous species grows on soil originated from rotting Pinus nigra J.F.Arnold wood.

F. Prosser

\section{Conocephalum salebrosum Szweyk., Buczkowska \& Odrzykoski (Conocephalaceae)}

+ TOS: San Pellegrino al Cassero, Sambuca Pistoiese (Pistoia), on vertical stillicidious sandstone wall along the street, accessed through the stone bridge on SS64 towards the 
locality of Pianezzi (UTM WGS84: 32T 657799.4880866), 660 m, 8 August 2017; ibidem, upstream, on stillicidious escarpment of sandstone rocks (UTM WGS84: 32T 658160.4880536), 808 m, 8 August 2017, F. Cheli (SIENA; Herb. Cheli). Species new for the flora of Toscana.

This species was described by Szweykowski et al. (2005) who defined the diagnostic features to distinguish between Conocephalum salebrosum and C. conicum, which, before this study, could be distinguished only genetically. Both occur in mostly shaded and usually calcareous habitats. C. salebrosum appears to be more tolerant to xeric habitats than C. conicum. C. salebrosum is widespread in Europe and, on the basis of the diagnostic differences between the two species, a review of other Italian specimens from herbaria would be appropriate in order to define their real occurrence on the Italian territory (Poponessi et al. 2014). In Toscana, it has been found in association with Palustriella commutata (Hedw.) Ochyra var. commutata, Didymodon tophaceus (Brid.) Lisa, and Pellia endiviifolia (Dicks.) Dumort. in Habitat 7220 "Petrifying springs with tufa formation (Cratoneurion commutati)" according to the Habitat Directive (Council Directive 92/43/EEC). It has been found sharing the habitat with $C$. conicum in both the recorded areas where a conspicuous spring waterflow is present all year round, even in summer (2015-2017 monitoring).

F. Cheli, I. Bonini

\section{Paludella squarrosa (Hedw.) Brid. (Meesiaceae)}

+ TAA: Klapfbergtal (a side-valley of the Val d'Ultimo), nearby the Klapferalm (Bolzano), on a moist and peaty slope with emerging rocks and percolating water (UTM WGS84: 32T 646331.5146651), 1945-1960 m, 27 June 2017, F. Sguazzin, G. Bergamo Decarli, D. Rigotti (Bryophytorum Herbarium F. Sguazzin). - Species new for the flora of Trentino-Alto Adige.

Paludella squarrosa is an Arctic species considered as a glacial relict (Dierßen 2001). According to Aleffi et al. (2008), the presence in Italy of P. squarrosa in restricted to a few mountain localities of Lombardia and Trentino-Alto Adige, while the presence in Piemonte has not been confirmed in the last 50 years. Associated bryophyte species include Cladopodiella fluitans (Nees) H.Bruch, Aulacomnium palustre (Hedw.) Schwägr., Campylium stellatum (Hedw.) Lange \& C.E.O.Jensen, Dichodontium palustre (Dicks.) M.Stech, Philonotis fontana (Hedw.) Brid., Pleurozium schreberi (Willd. ex Brid.) Mitt., Ptychostomum pseudotriquetrum (Hedw.) J.R.Spence \& H.P.Ramsay, Rhizomnium pseudopunctatum (Bruch \& Schimp.) T.J.Kop., Sanionia uncinata (Hedw.) Loeske, Scorpidium cossonii (Schimp.) Hedenäs, S. revolvens (Sw. ex anon.) Rubers, Sphagnum russowii Warnst., S. warnstorfii Russow, Straminergon stramineum (Dicks. ex Brid.) Hedenäs, and Tomentypnum nitens (Hedw.) Loeske. In Europe, P. squarrosa is classified as follows: Endangered (EN) in Italy, Austria, Latvia, Czech Republic, Slo- 
vakia, Romania, and Ukraine; Critically Endangered (CR) in Ireland and Germany; Vulnerable (VU) in Switzerland; Near Threatened (NT) in Estonia; Regional Extinct (RE) in Great Britain and Netherlands; Extinct (E) in Poland (Hodgetts 2015).

F. Sguazzin, G. Bergamo Decarli, D. Rigotti

\section{Tortula protobryoides R.H.Zander (Pottiaceae)}

+ EMR: Parco Regionale dei Gessi Bolognesi e Calanchi dell'Abbadessa (Bologna) on arid outcrops (UTM WGS84: 32T 690641.49222865), ca. 570 m, 22 April 2017, S. Poponessi, A. Cogoni (BPERU). - Species confirmed for Emilia-Romagna.

This taxon has been found on gypsum outcrops in dry and sunny stations associated with Tortella squarrosa (Brid.) Limpr., Syntrichia ruralis (Hedw.) F.Weber \& D.Mohr var. ruralis and Didymodon luridus Hornsch. The collected samples show cleistocarpous capsules. Tortula protobryoides has been recorded twice with recent reports in Marche and Sardegna, while its occurrence in Emilia-Romagna has not been confirmed over the last 50 years (Aleffi et al. 2008; Poponessi et al. 2014). The genus Protrobryum is accepted by Hill et al. (2006) for the single species Protrobryum bryoides (Dicks.) J.Guerra \& M.J.Cano. Ros et al. (2013) include this species in the genus Tortula as proposed by Zander (1993) and subsequently confirmed by Werner et al. $(2002,2004)$ on the basis of molecular data. In Europe, this species is located in central and eastern regions; it becomes much rarer in the north and south. However, it does occur in Hungary, Croatia, Greece, Spain, Portugal, Italy, and Macaronesia. This taxon has been assigned to the European Temperate geographic element (Smith 2004). Tortula protobryoides is considered Critically Endangered (CR) in Switzerland, Endangered (EN) in Bulgaria, Vulnerable (VU) in Estonia, Regional Extinct (RE) in Ireland and Nothern Ireland and Bedreigd Endangered (BE) in Netherlands in terms of Netherlands-specific categories (Hodgetts 2015).

S. Poponessi, A. Cogoni, M. Aleffi, R. Venanzoni

\section{FUNGI}

\section{Buelliella poetschii Hafellner (Dothideales)}

+ LAZ: Civita di Bagnoregio (Viterbo), on Endocarpon sp. (UTM WGS84: 33T 263304.4723472), 406 m, 17 January 2017, L. Gavrylenko (KHER No. 10527). Species new for the flora of Italy (Lazio).

This species grows on squamules of Endocarpon species. It is characterized by immersed apothecia-like pseudothecia, dark brown exciple and brown 1-septate ascospores 15.5-17.5 × 7.0-8.0 $\mu \mathrm{m}$ (Hafellner et al. 2008). There are two Buelliella spe- 
cies reported from Italy $-B$. minimula (Tuck.) Fink on thallus of Pertusaria pertusa (L.) Tuck. (Brackel 2015) and B. physciicola Poelt \& Hafellner on the thallus of Phaeophyscia sciastra (Ach.) Moberg (Hafellner 1979). Buelliella poetschii was recently reported from Austria (Hafellner et al. 2008), Belgium (Diederich et al. 2009), Bolivia (Flakus and Kukwa 2012), Peru (Etayo 2010a), Spain (Etayo 2010b), Switzerland (Hafellner et al. 2008), Russia (Urbanavichus and Urbanavichene 2011), the Netherlands (Diederich et al. 2009), Turkey (Yazıcı and Etayo 2013), Ukraine (Khodosovtsev et al. 2009), and USA (Hafellner et al. 2008).

V. Darmostuk, L. Gavrylenko

\section{Entorrhiza aschersoniana (Magnus) Lagerh. (Entorrhizaceae)}

+ CAL: Orto Botanico, Arcavacata (Cosenza), on roots of Juncus bufonius L. (UTM WGS84: 33 S 605886.4357371), m 203, 8 May 2007, D. Puntillo (CLU No. 66). New species for the flora of southern Italy (Calabria).

The genus Entorrhiza was established by Weber (1884) to accommodate fungi inducing galls on root tips of members of the Cyperaceae and Juncaceae. Magnus (1888) placed this species in the genus Schinzia Nägeli nom. illeg. Weber (1884) after a detailed investigation of the fungus in roots of Juncus bufonius; he considered the species as belonging to the Ustilaginales, erected the genus Entorrhiza and described the anatomy of the galls with illustrations of the fungus in the host cells. Entorrhiza aschersoniana is so far known from Europe, Central America and New Zealand (Vánky 2012). The phylogenetic position of Entorrhiza has long been debated (Begerow et al. 2006, Matheny et al. 2006, Hibbett et al. 2007). Recently, Bauer et al. (2015) proposed to include the genus in the new fungal phylum Entorrhizomycota. An extensive study of the genus Entorrhiza was carried out by Fineran (1973) in a doctoral thesis. Concerning Italy, there is an old record for Tirolo (Ciferri 1938) and a recent record for Friuli (Tomasi 2014).

D. Puntillo, A. Vizzini

Filicupula suboperculata (Döbbeler \& P. James) Y.J.Yao \& Spooner (Pyronemataceae)

+ ITALIA (CAL): Serra San Bruno (Vibo Valentia), Bosco di Santa Maria (UTM WGS84: 33T 614186.4268013), 820 m, 3 May 2015, W. v. Brackel, D. Puntillo (CLU No. 41). - New species for the flora of Italy (Calabria).

This species was originally described as Pseudonectria by Döbbeler and James (Döbbeler 1978) as the ascomata were interpreted as perithecia. Later, it was segregated into the genus Octosporella by Döbbeler (1979), and finally accommodated in the genus Filicupula by Yao and Spooner (1996), because the ascomata were interpreted as apothecia and not perithecia. Filicupula suboperculata grows on phyllodia of members 
of the liverwort genus Frullania, where it causes no visible damage. Until now it was reported only from Frullania tamarisci (L.) Dumort., while we found it on Frullania dilatata (L.) Dumort. The species was known only from the type locality in Scotland and from Bavaria/Germany (Brackel 2011). In Calabria it was collected on F. dilatata growing on bark of Abies alba Mill. in a site with oceanic climate.

W. v. Brackel, D. Puntillo

\section{Poronia punctata (L.) Fr. (Xylariaceae)}

+ CAL: Monte Manfriana, Pollino National Park (Cosenza), on horse dung (UTM WGS84: 33 606809.4414729), 1867 m, 19 November 2016, D. Puntillo (CLU No. 62).

+ SAR: Altopiano dei Cavalli, Codoleddu, Maracalagonis (Cagliari), on horse dung in marshy pasture (UTM WGS84: 32S 533856.4345064), $710 \mathrm{~m}, 11$ April 2017, D. Puddu (CAG No. P.31-59/1.1b); ibidem, on horse dung, at the edge of wet meadows and Mediterranean temporary ponds (UTM WGS84: 32S 533914.4344777), $710 \mathrm{~m}$, 17 May 2017, leg. G. Calvia, det. A. Vizzini (CAG. No. P.31-59/1.1a). - Species new for the flora of Sardegna and South Italy (Calabria).

Described by Linnaeus as Peziza punctata (1753) and then included in the genus Poronia by Fries (1846), this species is recognizable for the white, pezizoid and stipitate stromata with black immersed perithecia growing on equine dung. It is considered an endangered rare species and has been considered extinct in many countries (Ing 1993). It is also part of the Red List of the Italian flora (Rossi et al. 2013) as a Vulnerable species (VU). The (+)-isoepoxydon produced by the fungus has been identified as an intermediate in the biosynthesis of patulin, a mycotoxin inhibiting the growth of other fimicolous fungi (Gloer and Truckenbrod 1988). In Italy, it was recorded by Micheli (1729) and Traverso (1907), while Saccardo (1882) recorded it from Croatia (Dalmatia). Recently, it was reported from the Simbruini mountains (Lazio) by Granito and Lunghini (2006), from the Natural Reserve "Bosco della Favara e Bosco Granza" (Sicilia) by Venturella and Saitta (2009), and from the Regional Park of Monte Cucco (Umbria) by Minciarelli (2013). Owing to the large population of horses still living in the wild in some areas of the Pollino National Park and Codoleddu, this species is fairly widespread in these areas.

D. Puntillo, D. Puddu, A. Tatti

\section{Sporisorium schweinfurthianum (Thüm.) Karatygin (Ustilaginaceae)}

+ CAL: Deuda (Paola, Cosenza), sores in the ovaries of Imperata cylindrica (L.) Raeusch. (33S 589831.4353616) 8 m, 4 August 2013, D. Puntillo (CLU No. 70). - Species confirmed for the flora of Calabria. 
This very rare species was described by Thümen (1877) and accommodated in the genus Ustilago. Saccardo (1908) put it in the genus Sphacelotheca. Vánky (1983) then segregated this species in the genus Sporisororium, but with an invalid name. Finally, Karatygin in Karatygin and Azbukina (1989) validly combined it into Sporisorium. Sporisorium schweinfurthianum is distributed in S-E Europe, Africa and Asia (Denčev 1991; Wood et al. 2009; Vánky 2012). In Italy, this species is known from Sicilia (Palermo) and Calabria (Cosenza) (Ciferri 1938).

D. Puntillo

\section{Lichens}

\section{Agonimia opuntiella (Buschardt \& Poelt) Vězda (Verrucariaceae)}

+ CAM: Pisciotta(Salerno), on Olea europaea L. (UTM WGS84: 33T 519127.4440793), 230 m, 22 February 2011, leg. S. Ravera, G. Brunialti, det. S. Ravera (Herb. Ravera); Marina di Pisciotta (Salerno), on Olea europaea L. (UTM WGS84: 33T 519798.4439244), 40 m, 22 February 2011, leg. S. Ravera, G. Brunialti, det. S. Ravera (Herb. Ravera); Sacco Vecchia (Salerno), on Quercus ilex Willd. (UTM WGS84: 33T 531309.4470725), 600 m, 11 April 2011, leg. S. Ravera, G. Brunialti, det. S. Ravera (Herb. Ravera). - Species new for the flora of southern Italy (Campania).

Agonimia opuntiella is an epiphytic microlichen with squamulose thallus showing minutely papillate and hairy surface. This species grows on basal parts of old trees, usually on bark among mosses; it is overlooked in the field and often confused with young specimens of Phaeophyscia hirsuta (Mereschk.) Essl for the hairy surface.

These records confirm the scarce poleotolerance (Nimis 2016) of this species: both of the sites in the area of Pisciotta include undisturbed centenary trees in an olive orchard, and Sacco vecchia is an abandoned village at the foot of Mount Motola in the upper Cilento valley. Agonimia octospora is included in the national red list of epiphytic lichens as "Least Concern" (Nascimbene et al. 2013).

S. Ravera

\section{Cladonia humilis (With.) J.R.Laundon (Cladoniaceae)}

+ LOM: Malpaga (Bergamo), on sandy-pebbly calcareous soil in a dry grassland (UTM WGS84: 32T 558079.5051190), 183 m, 23 June 2016, G. Gheza (Herb. Gheza); Basella (Bergamo), on sandy-pebbly calcareous soil in a dry grassland (UTM WGS84: $32 \mathrm{~T}$ 557803.5050480), 176 m, 21 June 2016, G. Gheza (Herb. Gheza). - Species confirmed for the flora of Lombardia. 
Cladonia humilis is a terricolous species with a mainly Thyrrenian distribution in Italy (Nimis 2016). The two localities reported here are located in the nature reserve of Malpaga-Basella, within the Serio Regional Park, in wide calcareous dry grasslands near the rivercourse. The specimens analysed by thin layer chromatography always contained fumarprotocetraric acid and atranorin.

G. Gheza, H. Mayrhofer, J. Nascimbene

\section{Cladonia strepsilis (Ach.) Grognot (Cladoniaceae)}

+ PIE: Tenuta Bornago, Cameri (Novara), on sandy-pebbly soil in a dry Corynephorus grassland (UTM WGS84: 32T 476694.5044401), $171 \mathrm{~m}, 17$ June 2016, G. Gheza (Herb. Gheza). - Species confirmed for the flora of Piemonte.

+ LOM: Ansa di Castelnovate, Vizzola Ticino (Varese), on sandy-pebbly soil in a dry Corynephorus grassland (UTM WGS84: 32T 473961.5052563), 164 m, 16 June 2016, G. Gheza (Herb. Gheza); "La Promessa", Lonate Pozzolo (Varese), on sandy-pebbly soil in a small open Calluna heathland, (UTM WGS84: 32T 478604.5046292), 188 m, 15 March 2017, G. Gheza (Herb. Gheza). - Species confirmed for the flora of Lombardia.

Cladonia strepsilis is a terricolous species, which was considered restricted to the Alps in Italy (Nimis 2016). These new records show that, like other Cladonia species with a montane-alpine distribution in Italy (see Gheza 2015), C. strepsilis reaches the planitial belt following the rivercourse of the Ticino river. It was found associated with Cladonia foliacea (Huds.) Willd. or Cladonia cervicornis (Ach.) Flot. and, sometimes, also with Cladonia polycarpoides Nyl., in the Cladonietum foliaceae Klement, 1953 emend. Drehwald, 1993 and in the Pycnothelio-Cladonietum cervicornis Paus, 1997. The specimens analysed by thin layer chromatography always contained baeomycesic acid, squamatic acid and strepsilin.

\section{G. Gheza, H. Mayrhofer, J. Nascimbene}

\section{Dibaeis baeomyces (L.f.) Rambold \& Hertel (Icmadophilaceae)}

+ PIE: "Vauda" of Vauda Canavese (Torino), on bare clayey soil among Calluna vulgaris shrubs, in a dry Calluna heathland (UTM WGS84: 32T 388776.5013995), 434 m, 8 March 2016, G. Gheza, S. Assini (Herb. Gheza); "Vauda" of San Carlo Canavese (Torino), on bare clayey soil among Calluna vulgaris shrubs, in a dry Calluna heathland (UTM WGS84: 32T 392345.5012651), 370 m, 8 March 2016, G. Gheza, S. Assini (Herb. Gheza); Verrone (Biella), on bare clayey soil at the edge of a trail, in a dry Calluna heathland (UTM WGS84: 32T 431668.5036758), 250 m, 3 April 2017, G. Gheza, S. Assini (Herb. Gheza); Baraggione di Candelo near Cascina Bravetta, Massazza (Biella), on bare clayey soil among Calluna vulgaris shrubs, in a dry Calluna 
heathland (UTM WGS84: 32T 435996.5037555), 245 m, 7 July 2017, G. Gheza (Herb. Gheza). - Species confirmed for the flora of Piemonte.

+ LOM: Brughiera di Tornavento, Lonate Pozzolo (Varese), on bare soil among Polytrichum sp., at the edge of a dry Calluna heathland (UTM WGS84: 32T 478357.5049083), 202 m, 9 June 2017, G. Gheza (Herb. Gheza). - Species confirmed for the flora of Lombardia.

Dibaeis baeomyces is a terricolous species typical of pioneer and, often, disturbed areas (Nimis 2016). It has been always reported for montane-alpine localities in both Piemonte and Lombardia (see literature cited by Nimis 1993, 2016). Therefore, the records reported here are important to show that the species still exists in the Po Plain where well-preserved Calluna heathlands, which are one its main habitats (Nimis 2016), are still found. The record from the Brughiera di Tornavento confirms its occurrence in the area a long time after the last record by Cozzi (1917). It was always found sterile.

G. Gheza, J. Nascimbene, S. Assini

Gallowayella aphrodites (Kalb, Poelt \& S.Y.Kondr.) S.Y.Kondr., Fedorenko, S.Stenroos, Kärnefelt, Elix, Hur \& A.Thell (Teloschistaceae)

+ BAS: Rotonda (Potenza) in front of head office of Pollino National Park, m. 626, on bark of Tilia sp. (UTM WGS84: 33S 589202.4421804), 19 October 2015, D. Puntillo (CLU No. 16033). New species for the flora of Basilicata.

Originally described as Xanthoria aphrodites by Kalb et al. (Kondratyuk and Poelt 1997), this species was transferred to the genus Xanthomendoza by Søchting et al. (2002), then to the genus Oxneria by Kondratyuk and Kärnefelt (2003) and, finally, to the genus Gallowayella by Kondratyuk et al. (2012). In Italy, it is known only from Calabria (Puntillo and Puntillo 2015). Gallowayella aphrodites is easily confused with Xanthoria parietina (L.) Th.Fr., with which it is often found co-occurring in the same areas.

G. Potenza, D. Puntillo

\section{Lasallia pustulata (L.) Mérat (Umbilicariaceae)}

+ TOS: Valle del Crevole, close to the path Sentiero delle Miniere, Miniere di Murlo (Siena), on a vertical jasper outcrop, N. slope (UTM WGS84: 32T 693556.4779090), 218 m, 16 April 2014, A. Guttová, L. Paoli (SIENA); Valle del Crevole, close to the path Sentiero delle Miniere, Miniere di Murlo (Siena), on a horizontal jasper outcrop (UTM WGS84: 32T 693561.4779091), 218 m, 27 August 2016, L. Paoli, Z. Fačkovcová. - Species confirmed for the flora of Toscana.

The species has a pustulate upper surface with black clusters of coralloid isidia. It generally grows on siliceous rocks, standing stones and boulders. The presently 
described locality hosts a small population consisting of a few dozen thalli, growing both on horizontal and vertical outcrops. In 2015, two populations of $L$. pustulata were described on similar jasper outcrops in "Botro del Diavolo", in a remote hilly area SE of Livorno (Pasquinelli and Puccini 2016). A previously published record for Toscana refers to the Elba Island, where L. pustulata was observed on a granitic boulder on the E slope of Mt. Capanne (300 m a.s.l.), together with Anaptychia runcinata (With.) Laund. and Cladonia rangiformis Hoffm. (on soil) (Pišút 1997). Another record from Elba is available through a herbarium specimen collected by E. Albertshofer in 1965 and conserved at the Santa Barbara Botanic Garden Lichen Herbarium. The species was also reported on siliceous rocks on Capraia Island (Nimis et al. 1990). Herbarium specimens in TSB attest to its recent presence on Mt. Amiata, chiefly on siliceous rocks in Località Acquapassante (by M. Tretiach in 1992 and 2001) and Vivo d'Orcia (by M. Tretiach in 1992). A sample in SIENA (by J. Nascimbene in 1995) was collected on trachyte from Mt. Amiata. A publication by Feige et al. (1990) reported the use of L. pustulata from Mt. Amiata for the identification of radioactive contamination. Other herbarium specimens (SIENA) collected in 1993 (by Sforzi) and 2000 (by Casini) attest to the presence of L. pustulata in "Val di Farma" (Località La Pietra), between the provinces of Grosseto and Siena. In the past, this species was also found on Monte Pisano (by C. Bicchi in 1858, TSB) and in Vallombrosa (Mori 1883). Other records available in Toscana are prior to 1900; for a summary, see Nimis (1993).

L. Paoli, Z. Fačkovcová, A. Guttová

\section{References}

Aleffi M, Tacchi R, Cortini Pedrotti C (2008) Check-list of the Hornworts, liverworts and Mosses of Italy. Bocconea 22: 5-254.

Bauer R, Garnica S, Oberwinkler F, Riess K, Weiss M, Begerow D (2015) Entorrhizomycota: A new fungal Phylum reveals new perspective on the evolution of Fungi. PLoS ONE 10(7): e0128183. https://doi.org/10.1371/journal.pone. 0128183

Begerow D, Stoll M, Bauer R (2006) A phylogenetic hypothesis of Ustilaginomycotina based on multiple gene analyses and morphological data. Mycologia 98: 906-916. https://doi.or g/10.1080/15572536.2006.11832620

Brackel W (2011) Ein Fund von Filicupula suboperculata und weiterer hepaticoler Ascomyceten mit orangefarbigen Fruchtkörpern in Bayern. Berichte der Bayerischen Botanischen Gesellschaft 81: 145-148.

Brackel von W (2015) Lichenicolous fungi from Central Italy with notes on some remarkable hepaticolous, algicolous and lichenized fungi. Herzogia 28: 212-218. https://doi. org/10.13158/heia.28.1.2015.212

Ciferri R (1938) Flora Italica Cryptogama Pars I: Fungi Ustilaginales. Fasc. 17. Rocca S. Casciano. $443 \mathrm{pp}$. 
Cozzi C (1917) Manipolo di licheni della pianura milanese. Bullettino della Società Botanica Italiana 1917: 39-44.

Denčev CM (1991). New records of Bulgarian smut fungi (Ustilaginales). Sydowia 43: 15-22.

Diederich P, Ertz D, Broeck van den D, Boom PPG van den, Brand M, Sérusiaux E (2009) New or interesting lichens and lichenicolous fungi from Belgium, Luxembourg and northern France. XII. Bulletin de la Société des Naturalistes Luxembourgeois 110: 75-92.

Dierßen K (2001) Distribution, ecological amplitude and phytosociological characterization of European bryophytes. Bryophytorum Biblioteca, volume 56, 289 pp.

Döbbeler P (1978) Moosbewohnende Ascomyceten I. Die pyrenocarpen, den Gametophyten besiedelnden Arten. Mitteilungen der Botanischen Staatssammlung München 14: 360 pp.

Döbbeler P (1979) Untersuchungen an moosparasitischen Pezizales aus der Verwandtschaft von Octospora. Nova Hedwigia 31: 817-864.

Etayo J (2010a) Hongos liquénicolas de Perú, Homenaje a Rolf Santesson. Bulletin de la Société Linnéenne de Provence 61: 1-46.

Etayo J (2010b) Líquenes y hongos liquenícolas de Aragón. Guineana 16, 501 pp.

Feige GB, Niemann L, Jahnke S (1990) Lichens and mosses - silent chronists of the Chernobyl accident. Bibliotheca Lichenologica 38: 63-77.

Fineran J M (1973) Studies on the genus Entorrhiza C. Weber. University of Canterbury, Botany. Christchurch, 180 pp.

Flakus A, Kukwa M (2012) New records of lichenicolous fungi from Bolivia. Opuscula Philolichenum 11:36-48.

Fries E (1846) Summa vegetabilium Scandinaviae. Vol. I, Holmiae \& Lipsiae, 382 pp.

Gheza G (2015) Terricolous lichens of the western Padanian Plain: new records of phytogeographical interest. Acta Botanica Gallica: Botany Letters 162: 339-348. https://doi.org/10 $.1080 / 12538078.2015 .1108867$

Gloer JB, Truckenbrod SM (1988) Interference Competition among Coprophilous Fungi: Production of (+)-Isoepoxydon by Poronia punctata. Applied and Environmental Microbiology 54: 861-864.

Granito M, Lunghini D (2006) Updated observations on Poronia punctata. Micologia e Vegetazione Mediterranea 21: 71-76.

Hafellner J (1979) Karschia. Revision einer Sammelgattung an der Grenze von lichenisierten und nichtlichenisierten Ascomyceten. Beihefte zur Nova Hedwigia 62, 248 pp.

Hafellner J, Herzog G, Mayrhofer H (2008) Zur Diversität von lichenisierten und lichenicolen Pilzen in den Ennstaler Alpen (Österreich: Steiermark, Oberösterreich). Mitteilungen des Naturwissenschaftlichen Vereines für Steiermark 137: 131-204.

Hibbett DS, Binder M, Bischoff JF, Blackwell M, Cannon PF, Eriksson OE, et al. (2007) A higher level phylogenetic classification of the Fungi. Mycological Research 111: 509-547. https://doi.org/10.1016/j.mycres.2007.03.004

Hill MO, Bell N, Bruggeman-Nannenga MA, Brugués M, Cano MJ, Enroth J, Flatberg KI, Frahm J-P, Gallego MT, Garilleti R, Guerra J, Hedenäs L, Holyoak DT, Hyvönen J, Ignatov MS, Lara F, Mazimpaka V, Muñoz J, Söderström L (2006) An annotated checklist of the mosses of Europe and Macaronesia. Journal of Bryology 23: 198-267. https://doi. org/10.1179/174328206X119998 
Hodgetts NG (2015) Checklist and country status of European bryophytes - towards a new Red List for Europe. Irish Wildlife Manuals No. 84. National Parks and Wildlife Servica. Department of Arts, Heritage and the Gaeltacht. Ireland, 125 pp.

Karatygin IV, Azbukina ZM (1989) Opredelitel' gribov SSSR. Porjadok Golovnevye. Vyp. 1. Semejstvo Ustilagovye (Definitorium fungorum URSS. Ordo Ustilaginales. Fasc. 1. Familia Ustilaginaceae), 220 pp.

Khodosovtsev AY, Naumovich GO, Elix JA, Kondratyuk SY (2009) Lecanora panticapaensis sp. nova and Buelliella poetshii, two noteworthy species from Ukraine. Bibliotheca Lichenologica 100: 189-197.

Kondratyuk SY, Poelt J (1997) Two new Asian Xanthoria species (Teloschistaceae, Lichenized Ascomycotina) Lichenologist 29: 173-190. https://doi.org/10.1017/S0024282997000200

Kondratyuk SY, Kärnefelt I (2003) Revision of three natural groups of xanthorioid lichens (Teloschistaceae, Ascomycota). Ukrainian Botananical Journal 60: 427-437.

Ing B (1993) Towards a Red List of endangered European macrofungi. In: Pegler DN, Boddy B, Ing B, Kirk PM (Eds) Fungi of Europe: investigation, recording and conservation. The Royal Botanic Gardens Kew, 231-237.

Linnaeus C (1753) Species Plantarum. Imprensis Laurentius Salvius: 1180.

Magnus P (1888) Ueber einige Arten der Gattung Schinzia Näg. Berichte der Deutschen Botanischen Gesellschaft 6: 100-104.

Matheny PB, Gossmann JA, Zalar P, Kumar TKA, Hibbett DS (2006) Resolving the phylogenetic position of the Wallemiomycetes: an enigmatic major lineage of Basidiomycota. Canadian Journal of Botany 84: 1794-1805. https://doi.org/10.1139/b06-128

Micheli PA (1729) Nova Plantarum Genera. Paperinii, Firenze, 234 pp.

Minciarelli L (2013) Poronia punctata (L.) Fr. (Ascomycota, Xylariales) nei pascoli del Parco regionale del Monte Cucco (PG-Italia). Bollettino dell'Associazione Micologica ed Ecologica Romana 90: 46-50.

Mori A (1883) Contribuzione alla Flora Lichenologica della Toscana. Atti della Società Toscana di Scienze Naturali 6: 136.

Nascimbene J, Nimis PL, Ravera S (2013) Evaluating the conservation status of epiphytic lichens of Italy: a red list. Plant Biosystems 147: 898-904. https://doi.org/10.1080/1126 3504.2012.748101

Nimis PL (1993) The lichens of Italy: an annotated catalogue. Monografie XII. Museo Regionale di Scienze Naturali di Torino, 897 pp.

Nimis PL (2016) The Lichens of Italy. A second annotated catalogue. EUT. Trieste, 740 pp.

Nimis PL, Tretiach M, De Marchi A (1990). Contribution to lichen floristics in Italy. V. The lichens of the island of Capraia (Tuscan Archipelago). Cryptogamie, Bryologie Lichénologie 11: 1-30.

Pasquinelli P, Puccini F (2016) Lasallia pustulata (L.) Mérat. Una specie di lichene appartenente alla famiglia delle Umbilicariaceae repertato per la prima volta nelle Colline Livornesi. Codice Armonico 2016. Atti del Sesto Congresso di Scienze Naturali. Ambiente Toscano. Castiglioncello (LI), 13-15 Ottobre 2016: 230-237

Pišút I (1997) A small addition to the lichen flora of the Island of Elba (C. Italy). Flora Mediterranea $7: 145-147$. 
Poponessi S, Mariotti MG, Aleffi M, Venanzoni R (2014) Bryophytic similarity of the Italian regions with a focus on the Ligurian region. Plant Biosystems 148: 851-856. https://doi. org/10.1080/11263504.2014.949330

Priede A, Mežaka A (2016) Invasion of the alien moss Campylopus introflexus in cutaway peatlands. Herzogia 29: 35-51. https://doi.org/10.13158/heia.29.1.2016.35

Puglisi M, Campisi P, Dia MG, Privitera M (2015) New or interesting regional bryophyte records for Italian bryoflora. Flora Mediterranea 25(Special Issue): 193-198.

Puntillo D, Puntillo M (2015) Xanthomedoza (Teloschistacae) genere nuovo per la flora italiana. Notiziaro della Società Lichenologica Italiana 28: 12.

Ros RM, Mazimpaka V, Abou-Salama U, Aleffi M, Blockeel TL, Brugués M, Cano MJ, Cros RM, Dia MG, Dirkse GM, El-Saadawi W, Erdağ A, Ganeva A, González-Mancebo JM, Herrnstadt I, Khalil K, Kürschner H, Lanfranco E, Losada-Lima A, Refai MS, RodríguezNuñez S, Sabovljević M, Sérgio C, Shabbara H, Simsim M, Södertröm L (2007) Hepatics and Anthocerotes of the Mediterranean, an annotated checklist. Cryptogamie, Bryologie 28: 351-437.

Rossi G, Montagnani C, Gargano D, Peruzzi L, Abeli T, Ravera S, Cogoni A, Fenu G, Magrini S, Gennai M, Foggi B, Wagensommer RP, Venturella G, Blasi C, Raimondo FM, Orsenigo S (Eds) (2013) Lista Rossa della Flora Italiana. 1. Policy Species e altre specie minacciate. Comitato Italiano IUCN e Ministero dell'Ambiente e della Tutela del Territorio e del Mare, 54 pp.

Saccardo PA (1882) Sylloge fungorum omnium hucusque cognitorum, Padova, Vol. I: 348. https://doi.org/10.5962/bhl.title.80010

Saccardo PA (1908) Notae mycologicae. Series X. Annales Mycologici 6: 553-569.

Scortegagna S (2016) Briofite nuove o interessanti per il Veneto (NE Italia). Natura Vicentina 19: $37-84$.

Smith AJE (2004) The moss flora of Britain and Ireland (2nd Ed.). Cambridge University Press, 1012 pp. https://doi.org/10.1017/CBO9780511541858

Søchting U, Kärnefelt I, Kondratyuk S (2002) Revision of Xanthomendoza (Teloschistaceae, Lecanorales) based on morphology, anatomy, secondary metabolites and molecular data. Mitteilungen aus dem Institut fuer Allgemeine Botanik Hamburg 30-32: 225-240.

Szweykowski J, Buczkowska K, Odrzykoski IJ (2005) Conocephalum salebrosum (Marchantiopsida, Conocephalaceae) a new Holarctic liverwort species. Plant Systematics and Evolution 253: 133-158. https://doi.org/10.1007/s00606-005-0301-0

Tomasi E (2014) Indagine cecidologica sulla pianura e le lagune friulane (Italia NE). Atti del Museo Civico di Storia Naturale di Trieste 56: 43-202.

Traverso GB (1907) Flora Italica Cryptogama, pars. I. Fungi. Rocca S. Casciano.

Thümen F (1877) Mycotheca Universalis, centuriae 8. Bulletin de la Société Impériale des Naturalistes de Moscou: 726.

Urbanavichus G, Urbanavichene I (2011) New records of lichenicolous fungi from the Ural Mountains, Russia. Folia Cryptogamica Estonica 48: 119-124.

Vánky K (1983) Ustilaginales, Fasc. XVI-XVIII (Nos 376-450). Publications from the Herbarium University of Uppsala. 11: 12.

Vánky K (2012) Smut Fungi of the World. The American Phytopathological Society, St. Paul, Minnesota, USA. 1480 pp. 
Venturella G, Saitta A (2009) Poronia punctata, a rare ascomycetes from Italy. Bocconea 23: 277-279.

Weber C (1884) Über den Pilz der Wurzelanschwellungen von Juncus bufonius. Botanische Zeitung 42: 369-379.

Werner O, Ros RM, Cano MJ, Guerra J (2002) Tortula and some related genera (Pottiaceae, Musci): phylogenetic relationship based on chloroplast rps4 sequences. Plant Systematics and Evolution 235: 197-207. https://doi.org/10.1007/s00606-002-0230-0

Werner O, Ros RM, Cano MJ, Guerra J (2004) Molecular phylogeny of Pottiaceae (Musci) based on chloroplast rps4 sequence data. Plant Systematics and Evolution: 243: 147-164. https://doi.org/10.1007/s00606-003-0076-0

Wood AR, den Breeÿen A, Beed F (2009) First report of smut on Imperata cylindrica caused by Sporisorium schweinfurthianum in South Africa. Plant Disease 93: 322. https://doi. org/10.1094/PDIS-93-3-0322A

Yao Y-J, Spooner BM (1996) Notes on British Octosporella with a new genus Filicupula (Pezizales). Kew Bulletin 51: 193-196. https://doi.org/10.2307/4118759

Yazıcı K, Etayo J (2013) Buelliella, Codonmyces, and Polycoccum species new to Turkey. Mycotaxon 126: 45-50. https://doi.org/10.5248/126.45

Zander RH (1993) Genera of the Pottiaceae: mosses of harsh environment. Bulletin of the Buffalo society of natural science $32,378 \mathrm{pp}$. 